\title{
ОПРЕДЕЛЕНИЕ НЕФТЕЕМКОСТИ ТОРФОВ ТОМСКОЙ ОБЛАСТИ
}

\author{
() Н.В. Чухарева", Л.В. Шиимина, С.Г. Маслов \\ Национальный исследовательский Томский политехнический университет, \\ пр. Ленина, 30, Томск, 634034 (Россия), e-mail: natasha@tpu.ru
}

Дана оценка способности торфа разного типа, вида и степени разложения сорбировать товарную нефть и стабильный газовый конденсат. Показано влияние степени разложения, группового состава торфа на нефтеемкость. Установлено, что сорбционные свойства всех исследованных образцов торфа зависят от плотности сорбируемых нефтяных углеводородов.

Ключевые слова: торф, степень разложения, фракционный состав, технический анализ, групповой состав, сорбционные свойства, химическая структура, природные сорбенты, нефть, газовый конденсат, нефтеемкость, область распределения.

\section{Введение}

На сегодняшний день известен достаточно широкий спектр сорбционных материалов, позволяющих осуществлять процессы очистки различных компонентов биосферы от загрязняющих веществ, в частности, от нефти и нефтепродуктов при их разливах на грунте и водной поверхности. Большинство исследователей отмечают ряд критериев $[1,2]$, которые необходимо учитывать при выборе сорбента, основными из которых являются эффективность, сорбционная емкость, доступность, стоимость, срок годности сырья. Данным критериям вполне соответствует торф, который, согласно данным [3-5], относится к классу многокомпонентных полидисперсных полуколлоидных высокомолекулярных систем, характеризующихся как адсорбционный материал.

Обзор проведенных исследований $[5,6]$ показал, что на свойства сорбентов на основе торфа влияют такие его характеристики, как тип, степень разложения, зольность, дисперсность, влажность, групповой состав, структура торфа, а также вид сорбируемого нефтепродукта и его физико-химические свойства. На сегодняшний день большой объем исследований проведен для торфов северо-запада европейской части РФ, республики Татарстан, некоторых областей Западной Сибири. Широкое разнообразие торфов Томской области, с одной стороны, и большое количество нефтедобывающих, нефтеперерабатывающих предприятий, большая протяженность промысловых, межпромысловых, магистральных и технологических трубопроводов, с другой стороны, создают предпосылки для организации производства сорбентов нефтяных углеводородов на собственной территориальной сырьевой базе. В связи с этим исследования сорбционных свойств торфов по отношению к нефти и нефтепродуктам становятся актуальными.

Цель работы - определение нефтеемкости верховых, переходных и низинных торфов Томской области по отношению к товарным нефтям и стабильному газовому конденсату в зависимости от типа, вида, степени разложения, группового состава торфа и плотности сорбтива.

Чухарева Наталья Вячеславовна - доцент, кандидат химических наук, тел.: (3822) 41-90-17,

e-mail: natasha@tpu.ru

Шишмина Людмила Всеволодовна - доцент, кандидат химических наук, тел.: (3822) 42-13-52

Маслов Станислав Григорьевич - доцент, кандидат технических наук, тел.: (3822) 56-34-43

\section{Экспериментальная часть}

Исследование проводили на образцах верхового, переходного и низинного торфов месторождений Томской области. Характеристика торфа представлена в таблице 1 .

\footnotetext{
* Автор, с которым следует вести переписку.
} 
Образцы торфа высушивали до воздушно-сухого состояния. Из одной части торфа готовили аналитическую пробу под сито 0,25 мм для исследования на групповой состав по методике [7]. Результаты представлены в таблице 2 .

Вторую часть воздушно-сухого торфа измельчали под сито 4 мм для исследования нефтеемкости.

Таблица 1. Характеристика объектов исследования

\begin{tabular}{|c|c|c|c|c|c|c|c|c|c|}
\hline \multirow{2}{*}{ Месторождение } & \multirow{2}{*}{ Вид торфа } & \multirow{2}{*}{$\begin{array}{l}\mathrm{R}, \\
\%\end{array}$} & \multirow{2}{*}{ Шифр } & \multicolumn{3}{|c|}{ Технический анализ, \% } & \multicolumn{3}{|c|}{ Элементный состав, \% на daf } \\
\hline & & & & $W^{a}$ & $A^{d}$ & $V^{d a f}$ & $C$ & $H$ & $O+N+S$ \\
\hline \multicolumn{10}{|c|}{ Bерховые торфа } \\
\hline Семиозерье & сфагново-мочажинный & 5 & $768-3$ & 8,41 & 1,86 & 77,70 & 51,30 & 4,20 & 44,50 \\
\hline Березовая грива & сфагновый & 5 & $817-4$ & 6,96 & 7,42 & 76,21 & 55,20 & 5,80 & 39,00 \\
\hline Темное & фускум & 20 & $933-2$ & 11,16 & 4,73 & 76,00 & 49,19 & 5,10 & 45,71 \\
\hline Семиозерье & пушицево-сфагновый & 25 & $768-4$ & 8,17 & 2,94 & 73,50 & 56,80 & 6,50 & 36,70 \\
\hline Колпашевское & пушицево-сфагновый & 35 & $542-3$ & 6,59 & 2,89 & 71,00 & 57,20 & 5,70 & 37,10 \\
\hline \multicolumn{10}{|c|}{ Переходные торфа } \\
\hline Семиозерье & шейхцериевый & 20 & $768-5$ & 7,35 & 9,50 & 73,70 & 52,20 & 5,00 & 42,80 \\
\hline Васюганское & осоково-сфагновый & 30 & $397-2$ & 7,20 & 4,31 & 71,10 & 51,70 & 6,40 & 41,90 \\
\hline \multicolumn{10}{|c|}{ Низиннье торфа } \\
\hline Клюквенное & древесный & 30 & $932-3$ & 8,76 & 11,18 & 68,30 & 49,60 & 4,10 & 46,30 \\
\hline Таганское & осоковый & 35 & $972-1$ & 11,1 & 12,94 & 68,40 & 53,40 & 5,90 & 40,70 \\
\hline
\end{tabular}

Примечания. $\mathrm{R}$ - степень разложения торфа; $\mathrm{W}^{\mathrm{a}}$ - влажность аналитическая; $\mathrm{A}^{\mathrm{d}}-$ зольность, на сухое вещество;

$\mathrm{V}^{\mathrm{daf}}$ - выход летучих веществ, на горючую массу.

Таблица 2. Групповой состав верхового, переходного и низинного торфов

\begin{tabular}{|c|c|c|c|c|c|}
\hline \multirow{2}{*}{ Шифр торфа } & \multicolumn{5}{|c|}{ Групповой состав, \% на сухое вещество } \\
\hline & Битумы & ВРВ+ЛГВ & $\Gamma K$ & $\Phi K$ & Лигнин + целлюлоза \\
\hline \multicolumn{6}{|c|}{ Bерховиге торфа } \\
\hline $768-3$ & 4,2 & 46,6 & 6,1 & 22,9 & 20,2 \\
\hline $817-4$ & 2,9 & 46,7 & 18,4 & 17,5 & 14,5 \\
\hline $933-2$ & 4,5 & 54,7 & 9,0 & 17,2 & 14,6 \\
\hline $768-4$ & 6,3 & 34,6 & 25,1 & 16,3 & 17,7 \\
\hline $542-3$ & 9,7 & 32,2 & 30,4 & 15,1 & 12,6 \\
\hline \multicolumn{6}{|c|}{ Переходные торфа } \\
\hline $768-5$ & 4,3 & 33,2 & 16,4 & 32,1 & 14,0 \\
\hline $397-2$ & 5,6 & 30,2 & 25,2 & 23,6 & 15,4 \\
\hline \multicolumn{6}{|c|}{ Низинные торфа } \\
\hline $932-3$ & 3,7 & 25,7 & 41,7 & 8,8 & 20,1 \\
\hline $972-1$ & 2,6 & 32,7 & 35,1 & 17,6 & 12,0 \\
\hline
\end{tabular}

Методика определения нефтеемкости торфа. За основу была взята методика [1] с корректировкой, изложенной в [8]. Условия проведения эксперимента были изменены вследствие использования 3-х сеток разной массы $\left(G_{c_{i}}\right), 3-$ х часовых стекол разной массы $\left(G_{c m_{i}}\right)$ и различных навесок торфа $\left(G_{T_{i}}\right)$. Средняя масса торфа составила 3 г, отклонение данного показателя по всем экспериментам - $\pm 5 \%$. Средняя масса нефти, удерживаемая навеской торфа:

$$
G_{3_{c p}}=\frac{\sum_{i=1}^{n}\left[G_{2_{i}}-G_{c_{i}}-G_{c m_{i}}-G_{T_{i}}-G_{0_{i}}\right]}{n}, \text { при } n \geq 5, P \geq 0,95,
$$

где $\mathrm{G}_{2 \mathrm{i}}$ - масса часового стекла, сетки с удерживаемой нефтью, навеской торфа с удерживаемой нефтью в і-м эксперименте, г; n - количество экспериментов; $G_{c_{i}}$ - масса i-й сетки, г; $G_{c m_{i}}-$ масса і-го часового стекла, г; $G_{0_{i}}-$ масса нефти, удерживаемая і-й сеткой, г [8]; $G_{T_{i}}-$ масса і-й навески торфа, г; $P-$ степень сходимости результатов измерений нефтеемкости.

Нефтеемкость влажного торфа $\boldsymbol{G}_{\boldsymbol{N}}$ составляет: 


$$
\begin{gathered}
G_{N}=\frac{G_{3 c p}}{G_{T c p}}, \\
G_{T_{c p}}=\frac{\sum_{i=1}^{n} G_{T_{i}}}{n} .
\end{gathered}
$$

Нефтеемкость сухого торфа $\boldsymbol{G}_{N}{ }^{\boldsymbol{d}}$ :

$$
\begin{aligned}
& G_{N}{ }^{d}= \frac{G_{3_{c p}}}{G_{T_{c p}}{ }^{d}}, \\
& G_{T_{c p}}{ }^{d}=G_{T_{c p}} \frac{100-W^{a}}{100} .
\end{aligned}
$$

В качестве сорбтива были использованы товарные нефти (ТН) различной плотности и стабильный

\begin{tabular}{|c|c|c|c|c|c|c|}
\hline $\begin{array}{c}\text { Шифр } \\
\text { сорбируемых } \\
\text { веществ }\end{array}$ & $\begin{array}{c}\text { Плотность при } \\
20{ }^{\circ} \mathrm{C}, \text { кг } / \mathrm{m}^{3}\end{array}$ & $\begin{array}{c}\text { Массовая } \\
\text { доля воды, \% }\end{array}$ & $\begin{array}{c}\text { Массовая концен- } \\
\text { трация хлористых } \\
\text { солей, мг/дм }{ }^{3}\end{array}$ & $\begin{array}{c}\text { Массовая } \\
\text { доля } \\
\text { серы, \% }\end{array}$ & $\begin{array}{c}\text { Выход фракций } \\
\text { при температуре } \\
200{ }^{\circ} \mathrm{C}, \%\end{array}$ & $\begin{array}{c}\text { Давление } \\
\text { насыщенных } \\
\text { паров, кПа }\end{array}$ \\
\hline TH A & 874,0 & 0,03 & 12,0 & 0,15 & 14,0 & 28,5 \\
\hline TH B & 844,3 & 0,08 & 8,9 & 0,61 & 38,0 & 41,0 \\
\hline TH C & 824,0 & 0,08 & 25,4 & 0,42 & 34,5 & 42,0 \\
\hline TH D & 796,2 & 0,03 & 7,39 & 0,33 & 52,0 & 63,5 \\
\hline СГК Е & 695,6 & 0,03 & 0,79 & 0,01 & 93,0 & 59,0 \\
\hline
\end{tabular}
газовый конденсат (СГК) месторождений Томской области и Красноярского края. Характеристика сорбируемых веществ представлена в таблице 3.

Таблица 3. Характеристика товарных нефтей стабильного газового конденсата

\section{Результаты и обсуждение}

Результаты исследования нефтеемкости торфов относительно различных сорбируемых ТН и СГК представлены в таблицах 4-8, рисунках 1-3 (P = 0,95, абсолютная погрешность - $\pm 2,5 \%)$. Анализ полученных данных целесообразно провести по следующей схеме:

- влияние типа, вида и степени разложения торфа на нефтеемкость;

- влияние компонентного состава торфа на нефтеемкость;

- влияние плотности ТН и СГК на нефтеемкость торфа.

В представленной работе показано, что для различных ТН наибольшая нефтеемкость на сухое вещество торфа $\boldsymbol{G}_{N}{ }^{d}$ характерна для верховых торфов малой степени разложения, $\mathrm{R}=5 \%$, сфагновомочажинного и сфагнового видов. Значения нефтеемкости для легких и средних товарных нефтей находятся в области 6,02-9,98 г/1 г торфа (табл. 4-7). Высокая нефтеемкость верховых торфов моховой группы также отмечена в работах $[6,9]$.

По стабильному газовому конденсату показатели $\boldsymbol{G}_{N}{ }^{d}$ для указанных образцов получены в более низкой области: 2,97-3,09 г/1 г торфа (табл. 8).

Исследования $\boldsymbol{G}_{\boldsymbol{N}}{ }^{\boldsymbol{d}}$ переходных и низинных торфов средней степени разложения для ТН показали пределы 2,11-4,26 г/1 г торфа (табл. 4-7). По СГК для вышеуказанных образцов значения $\boldsymbol{G}_{N}{ }^{d}-$ от $1,81-$ 2,93 (табл. 8).

Данные рисунка 1 свидетельствуют о влиянии степени разложения всех торфов верхового, переходного и низинного типа на показатель $\boldsymbol{G}_{N}{ }^{d}$ :

1. При увеличении степени разложения верховых торфов снижается их нефтеемкость (рис. 1a).

2. Для торфов переходного типа отмечено незначительное возрастание показателя $\boldsymbol{G}_{N}{ }^{d}$ с ростом R от 20 до $30 \%$ (рис. 1б), при этом абсолютные значения прироста $\boldsymbol{G}_{N}{ }^{d}$ для ТН шифров А, В, С, D находятся в интервале от 0,17 до 0,58 г/1 г торфа.

3. Для низинных торфов отмечено большее возрастание показателя $\boldsymbol{G}_{\boldsymbol{N}}{ }^{d}$ с повышением $\mathrm{R}$ от 30 до $35 \%$ (рис. 1в), абсолютные значения прироста $\boldsymbol{G}_{N}{ }^{d}$ для ТН В, С, D находятся в интервале от 0,54 до 0,84 г/1 г торфа, за исключением сорбтива ТН А. 
Таблица 4. Нефтеемкость торфов различного типа, вида и степени разложения по отношению к товарной нефти А

\begin{tabular}{|c|c|c|c|c|c|}
\hline \multicolumn{4}{|c|}{ Характеристика сорбционного материала } & \multirow{2}{*}{$\begin{array}{c}\boldsymbol{G}_{\boldsymbol{N}}, \\
\text { г/1 г торфа }\end{array}$} & \multirow{2}{*}{$\begin{array}{c}\boldsymbol{G}_{\boldsymbol{N}}{ }^{d}, \\
\text { г/1 г торфа }\end{array}$} \\
\hline Шифр & Тип & Вид & $\mathrm{R}, \%$ & & \\
\hline $768-3$ & \multirow{5}{*}{ верховой } & сфагново-мочажинный & 5 & 9,22 & 9,98 \\
\hline $817-4$ & & сфагновый & 5 & 7,6 & 8,28 \\
\hline $933-2$ & & фускум & 20 & 2,71 & 3,06 \\
\hline $768-4$ & & пушицево-сфагновый & 25 & 3,11 & 3,36 \\
\hline $542-3$ & & пушицево-сфагновый & 35 & 1,55 & 1,66 \\
\hline $768-5$ & \multirow{2}{*}{ переходный } & шейхцериевый & 20 & 2,68 & 2,88 \\
\hline $397-2$ & & осоково-сфагновый & 30 & 3,21 & 3,46 \\
\hline $932-3$ & \multirow{2}{*}{ низинный } & древесный & 30 & 3,29 & 4,25 \\
\hline $972-1$ & & осоковый & 35 & 3,79 & 4,26 \\
\hline
\end{tabular}

Примечание. Плотность товарной нефти $\mathbf{A} 873,2$ кг $/ \mathrm{M}^{3}$, при $20^{\circ} \mathrm{C}$.

Таблица 5. Нефтеемкость торфов различного типа, вида и степени разложения по отношению к товарной нефти В

\begin{tabular}{|c|c|c|c|c|c|}
\hline \multicolumn{4}{|c|}{ Характеристика сорбционного материала } & \multirow{2}{*}{$\begin{array}{c}\boldsymbol{G}_{\boldsymbol{N}}, \\
\text { г/1 г торфа }\end{array}$} & \multirow{2}{*}{$\begin{array}{c}\boldsymbol{G}_{\boldsymbol{N}}{ }^{\boldsymbol{1}}, \\
\text { г/1 г торфа }\end{array}$} \\
\hline Шифр & Тип & Вид & $\mathrm{R}, \%$ & & \\
\hline $768-3$ & & сфагново-мочажинный & 5 & 8,41 & 9,17 \\
\hline $817-4$ & & сфагновый & 5 & 7,51 & 8,07 \\
\hline $933-2$ & & фускум & 20 & 3,23 & 3,63 \\
\hline $768-4$ & верховой & пушицево-сфагновый & 25 & 2,62 & 2,87 \\
\hline $542-3$ & & пушицево-сфагновый & 35 & 1,50 & 1,61 \\
\hline $768-5$ & пепеуолний & шейхцериевый & 20 & 2,61 & 2,84 \\
\hline $397-2$ & переходныи & осоково-сфагновый & 30 & 3,00 & 3,20 \\
\hline $932-3$ & & древесный & 30 & 2,52 & 2,77 \\
\hline $972-1$ & низинный & осоковый & 35 & 3,11 & 3,50 \\
\hline
\end{tabular}

Примечание. Плотность товарной нефти В 844,3 кг $/ \mathrm{M}^{3}$, при $20^{\circ} \mathrm{C}$.

Таблица 6. Нефтеемкость торфов различного типа, вида и степени разложения по отношению к товарной нефти $\mathbf{C}$

\begin{tabular}{|c|c|c|c|c|c|}
\hline \multicolumn{4}{|c|}{ Характеристика сорбционного материала } & \multirow{2}{*}{$\begin{array}{c}\boldsymbol{G}_{\boldsymbol{N}}, \\
\text { г/1 г торфа }\end{array}$} & \multirow{2}{*}{$\begin{array}{c}\boldsymbol{G}_{\boldsymbol{N}}{ }^{d}, \\
\text { г/1 г торфа }\end{array}$} \\
\hline Шифр & Тип & Вид & $\mathrm{R}, \%$ & & \\
\hline $768-3$ & \multirow{5}{*}{ верховой } & сфагново-мочажинный & 5 & 8,28 & 9,02 \\
\hline $817-4$ & & сфагновый & 5 & 6,77 & 7,28 \\
\hline $933-2$ & & фускум & 20 & 1,96 & 2,22 \\
\hline $768-4$ & & пушицево-сфагновый & 25 & 2,49 & 2,71 \\
\hline $542-3$ & & пушицево-сфагновый & 35 & 1,32 & 1,42 \\
\hline $768-5$ & \multirow{2}{*}{ переходный } & шейхцериевый & 20 & 2,63 & 2,85 \\
\hline $397-2$ & & осоково-сфагновый & 30 & 2,81 & 3,02 \\
\hline $932-3$ & \multirow{2}{*}{ низинный } & древесный & 30 & 2,22 & 2,59 \\
\hline $972-1$ & & осоковый & 35 & 3,05 & 3,43 \\
\hline
\end{tabular}

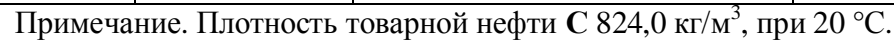

Таблица 7. Нефтеемкость торфов различного типа, вида и степени разложения по отношению к товарной нефти D

\begin{tabular}{|c|c|c|c|c|c|}
\hline \multicolumn{4}{|c|}{ Характеристика сорбционного материала } & \multirow{2}{*}{$\begin{array}{c}\boldsymbol{G}_{\boldsymbol{N}}, \\
\text { г/1 г торфа }\end{array}$} & \multirow{2}{*}{$\begin{array}{c}\boldsymbol{G}_{\boldsymbol{N}}{ }^{d}, \\
\Gamma / 1 \text { г торфа }\end{array}$} \\
\hline Шифр & Тип & Вид & $\mathrm{R}, \%$ & & \\
\hline $768-3$ & & сфагново-мочажинный & 5 & 7,82 & 8,50 \\
\hline $817-4$ & & сфагновый & 5 & 5,61 & 6,02 \\
\hline $933-2$ & верховой & фускум & 20 & 1,48 & 1,67 \\
\hline $768-4$ & & пушицево-сфагновый & 25 & 2,54 & 2,68 \\
\hline $542-3$ & & пушицево-сфагновый & 35 & 1,33 & 1,37 \\
\hline $768-5$ & пгерехпный & шейхцериевый & 20 & 2,00 & 2,16 \\
\hline $397-2$ & переходныи & осоково-сфагновый & 30 & 2,39 & 2,48 \\
\hline $932-3$ & НИРИНUӖ & древесный & 30 & 1,98 & 2,11 \\
\hline $972-1$ & Низинныи & осоковый & 35 & 2,42 & 2,65 \\
\hline
\end{tabular}

Примечание. Плотность товарной нефти D 796,2 кг $/ \mathrm{M}^{3}$, при $20^{\circ} \mathrm{C}$. 
Таблица 8. Нефтеемкость торфов различного типа, вида и степени разложения по отношению к стабильному газовому конденсату

\begin{tabular}{|c|c|c|c|c|c|}
\hline \multicolumn{4}{|c|}{ Характеристика сорбционного материала } & \multirow{2}{*}{$\begin{array}{c}\boldsymbol{G}_{\boldsymbol{N}}, \\
\text { г/1 г торфа }\end{array}$} & \multirow{2}{*}{$\begin{array}{c}\boldsymbol{G}_{\boldsymbol{N}}{ }^{\boldsymbol{d}}, \\
\text { г/1 г торфа }\end{array}$} \\
\hline Шифр & Тип & Вид & $\mathrm{R}, \%$ & & \\
\hline $768-3$ & \multirow{5}{*}{ верховой } & сфагново-мочажинный & 5 & 2,89 & 3,09 \\
\hline $817-4$ & & сфагновый & 5 & 2,64 & 2,97 \\
\hline $933-2$ & & фускум & 20 & 1,52 & 1,72 \\
\hline $768-4$ & & пушицево-сфагновый & 25 & 1,50 & 1,80 \\
\hline $542-3$ & & пушицево-сфагновый & 35 & 1,24 & 1,31 \\
\hline $768-5$ & \multirow{2}{*}{ переходный } & шейхцериевый & 20 & 1,97 & 2,11 \\
\hline $397-2$ & & осоково-сфагновый & 30 & 2,04 & 2,19 \\
\hline $932-3$ & \multirow{2}{*}{ низинный } & древесный & 30 & 1,65 & 1,81 \\
\hline $972-1$ & & осоковый & 35 & 2,61 & 2,93 \\
\hline
\end{tabular}

Примечание. Плотность стабильного газового конденсата $\mathbf{E} 695,6$ кг $/ \mathrm{M}^{3}$, при $20^{\circ} \mathrm{C}$.

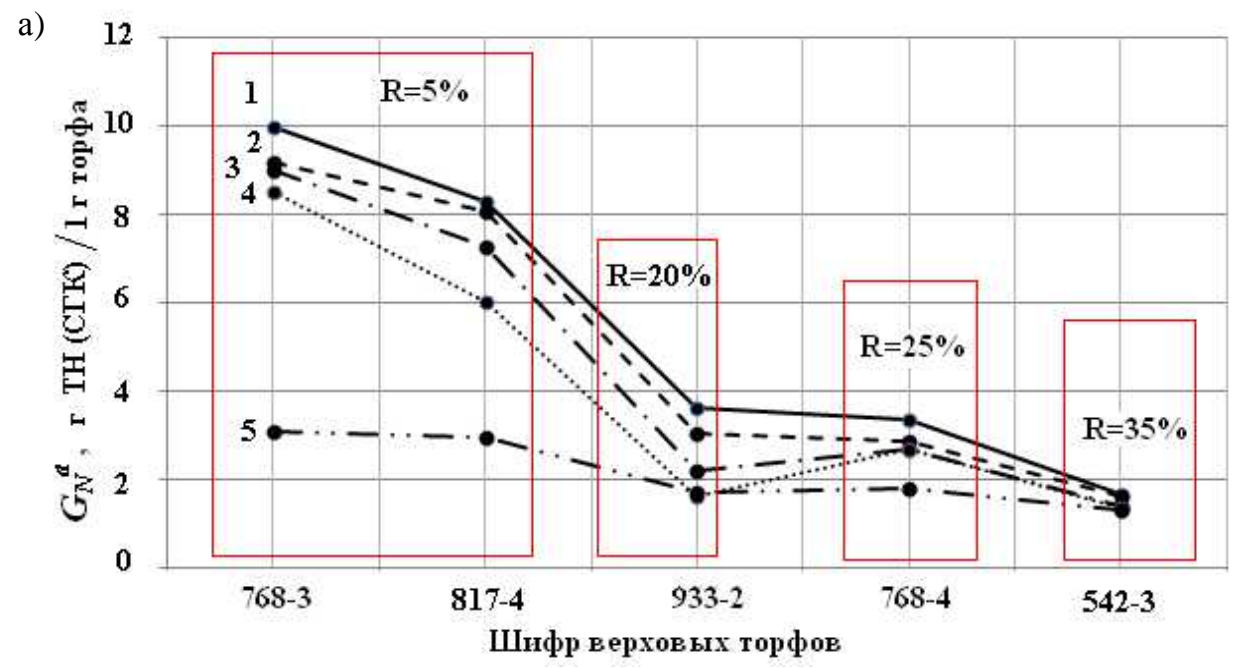

б)

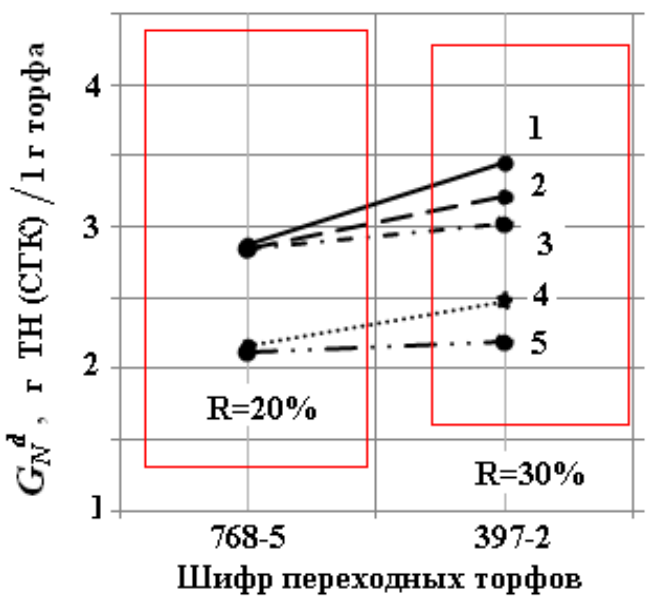

B)

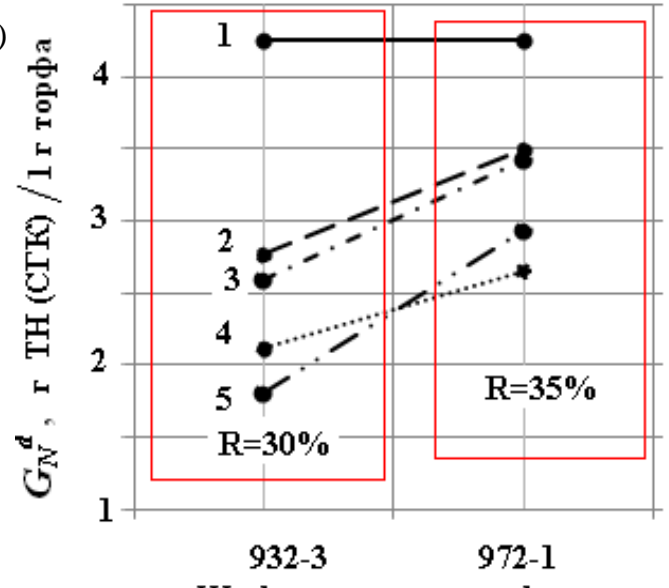

Шифр низинных торфов

Рис. 1. Изменение показателя нефтеемкости $\boldsymbol{G}_{\boldsymbol{N}}{ }^{\boldsymbol{d}}$ для верховых (а), переходных (б), низинных (в) торфов различного типа, вида и степени разложения по отношению к товарной нефти и стабильному газовому конденсату: 1 - товарная нефть $\mathbf{A}\left(\rho=873,5\right.$ кг $\left./ \mathrm{M}^{3}\right) ; 2$ - товарная нефть $\mathbf{B}\left(\rho=844,3 \mathrm{\kappa} / \mathrm{M}^{3}\right) ; 3$ - товарная нефть $\mathbf{C}\left(\rho=824,0\right.$ кг $\left./ \mathrm{M}^{3}\right) ; 4$ - товарная нефть $\mathbf{D}\left(\rho=796,2\right.$ кг $\left./ \mathrm{M}^{3}\right) ; 5$ - стабильный газовый конденсат $\mathbf{E}$ $\left(\rho=695,6 \kappa \Gamma / \mathrm{M}^{3}\right)$ 
a)

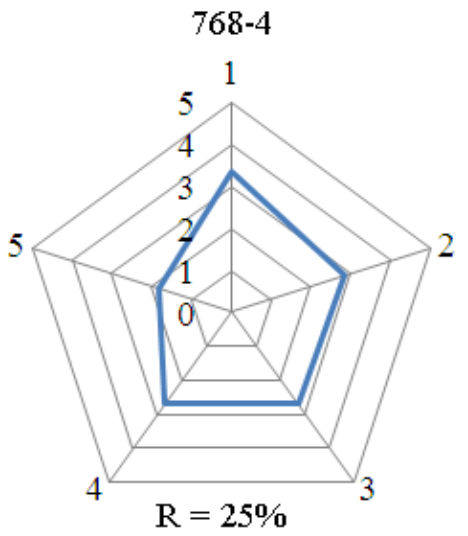

г)

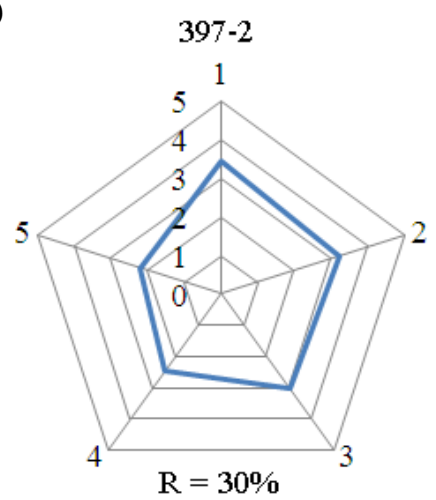

б)

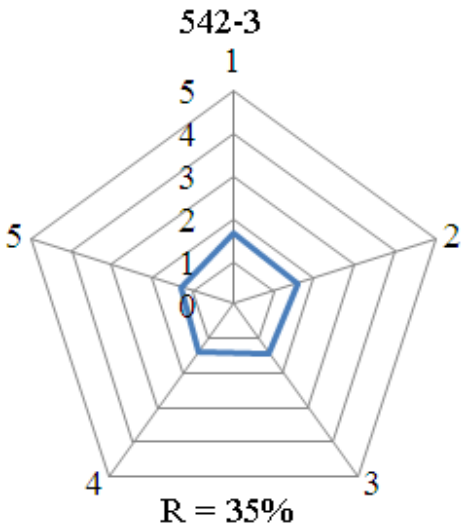

Д)

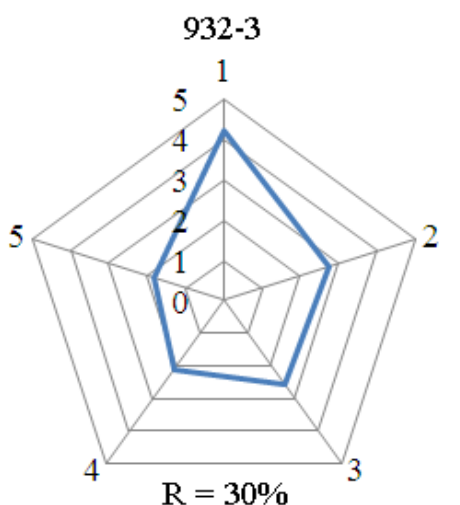

в)

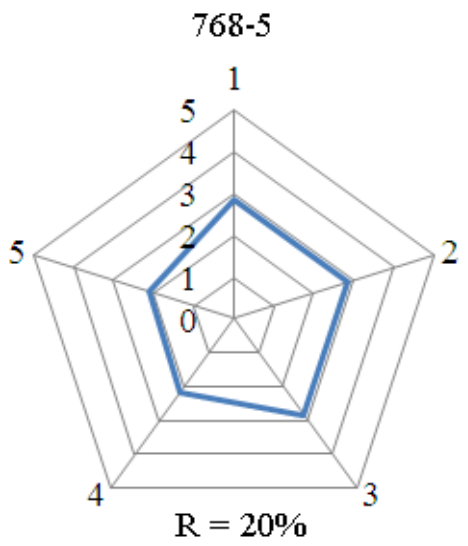

e)

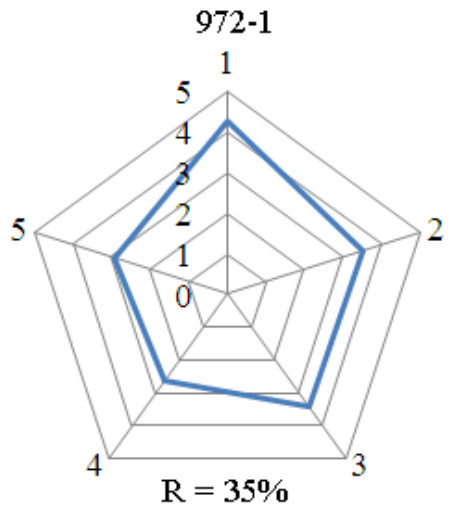

Рис. 2. Площади распределения показателя нефтеемкости $\boldsymbol{G}_{\boldsymbol{N}}{ }^{\boldsymbol{}}$ для верховых (а, б), переходных (в, г), низинных (д, е) торфов средней степени разложения по отношению к товарной нефти и стабильному газовому конденсату: 1 - товарная нефть $\mathbf{A}\left(\rho=873,5 \mathrm{\kappa r} / \mathrm{M}^{3}\right) ; 2$ - товарная нефть $\mathbf{B}\left(\rho=844,3 \mathrm{\kappa} / \mathrm{M}^{3}\right)$;

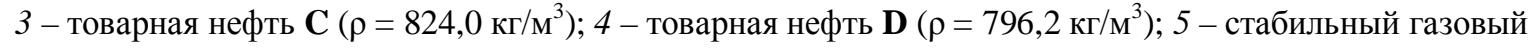
конденсат $\mathbf{E}\left(\rho=695,6\right.$ кг/м $\left.{ }^{3}\right)$

a)
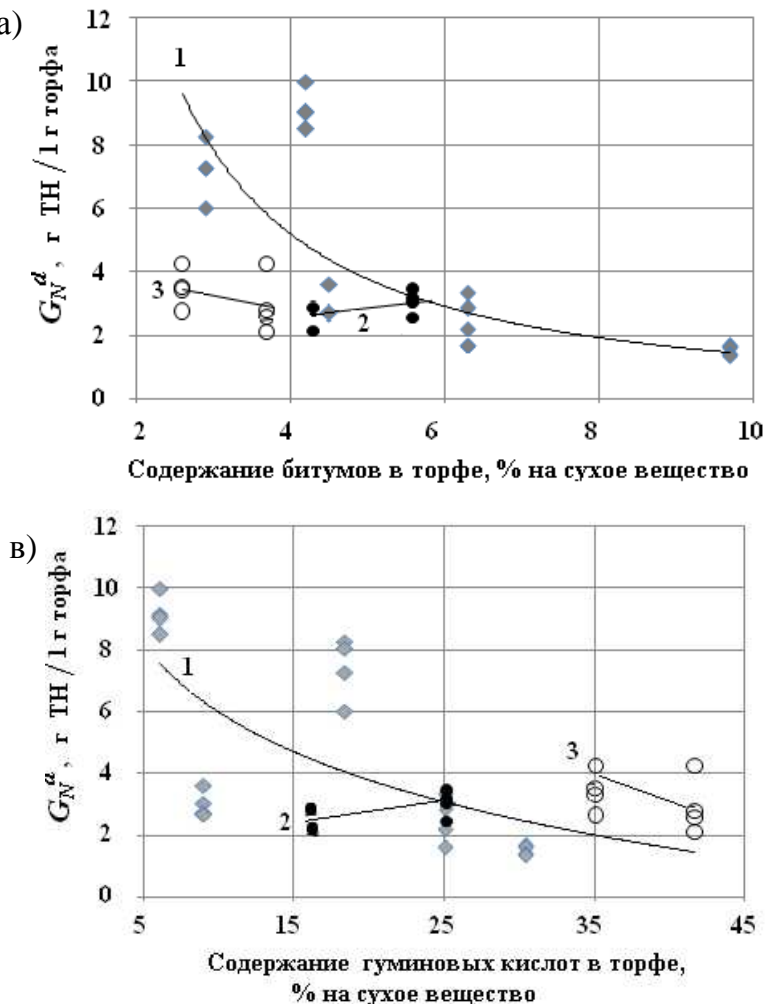

б)

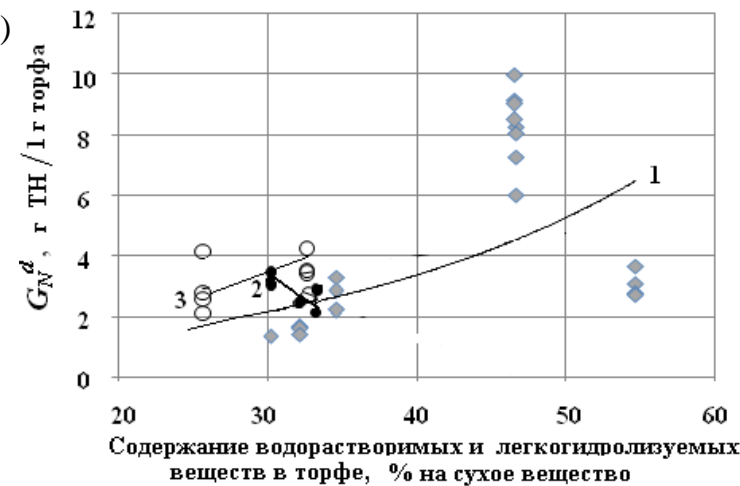

г)

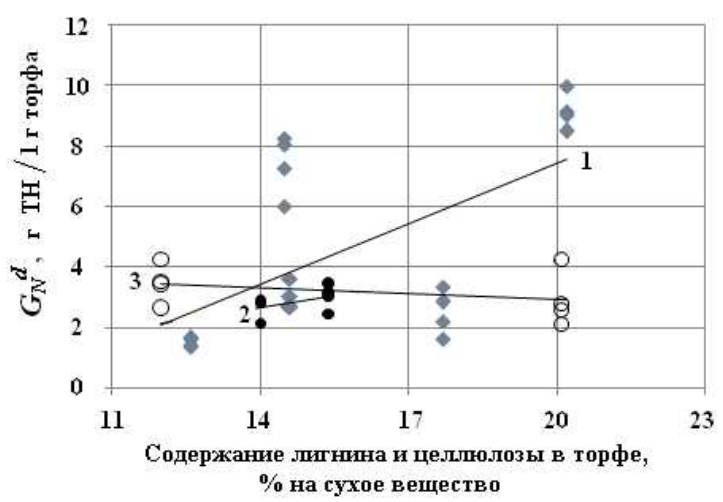

Рис. 3. Влияние группового состава торфов на изменение показателя нефтеемкости $\boldsymbol{G}_{N}{ }^{d}: 1-$ верховые; 2 - переходные; 3 - низинные торфа 
Авторы [6] считают, что увеличение степени разложения как верховых, так и низинных торфов приводит к снижению его нефтеемкости, что связано с влиянием степени биохимического распада растенийторфообразователей на структуру торфа. Результаты, полученные в нашей работе, совпадают с вышеуказанной зависимостью только для торфов верхового типа.

На рисунке 2 представлено распределение показателя $\boldsymbol{G}_{\boldsymbol{N}}{ }^{\boldsymbol{d}}$ для верховых, переходных, низинных торфов средней степени разложения по отношению к ТН и СГК. Площадь пятиугольников (в соответствии с числом исследованных сорбтивов) соответствует сорбционной способности индивидуального образца сорбента, и характеризует его универсальность. Чем больше площадь фигуры, тем к большему числу углеводородов разной плотности рационально применение конкретного торфа. Таким образом, самым универсальным является низинный осоковый торф, $\mathrm{R}=35 \%$, наименее универсальным - верховой пушицево-сфагновый, $\mathrm{R}=35 \%$.

Известно, что с изменением степени разложения торфа изменяется его групповой состав [7]. Следовательно, групповой состав является еще одним фактором, влияющим на нефтеемкость торфяного сорбента. В работах $[6,10]$ приведены результаты экспериментов по оценке влияния отдельных компонентов органической массы торфа на его сорбционные свойства. Четко прослежено, что с увеличением содержания битумов (верховой тип), гуминовых кислот (верховой и низинный тип) в торфе его емкость сорбции по нефтемаслопродуктам падает. С.Р. Испирян [6] подчеркивает, что малое количество битумов является причиной кажущегося отрицательного влияния на сорбционные характеристики природного сорбента, потому что удаление битумов приводит к снижению емкости сорбции торфа. Водорастворимые, легкогидролизуемые вещества (верховой тип) и целлюлоза (верховой и низинный тип) улучшают сорбционные свойства торфа.

Результаты исследования зависимости нефтеемкости ТН от группового состава объектов исследования представлены на рисунке 3. Из них следует, что для верховых и низинных торфов показатель $\boldsymbol{G}_{N}^{\boldsymbol{d}}$ снижается при увеличении содержания битумов (рис. 3а). Возрастание доли водорастворимых и легкогидролизуемых веществ (верховой и низинный торф), увеличение лигнина и целлюлозы (верховой торф) способствуют улучшению его сорбционных свойств (рис. 3б, г). Для исследованных объектов низинного торфа влияние лигнина и целлюлозы на нефтеемкость не установлено.

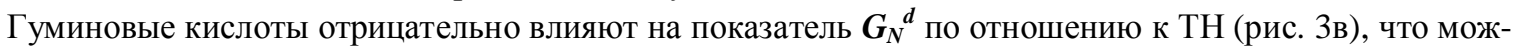
но связать с гидрофильностью данных групповых составляющих, обусловленной наличием в их составе активных функциональных кислых групп - карбоксильных и гидроксильных [12]. Кроме того, агрегаты гуминовых кислот накапливаются в полостях клеток неразложившихся растений, препятствуя тем самым проникновению туда молекул нефтепродуктов [6].

Для образцов переходного торфа не выявлено явной зависимости нефтеемкости от компонентов группового состава, что может быть связано с малым количеством образцов, узким интервалом степени разложения и содержания групповых компонентов, особенностями физической структуры торфа.

Средством регулирования нефтеемкости торфов различного типа, вида и степени разложения может являться их термическая модификация, которая приведет к изменению состава и свойств групповых составляющих.

Исследование влияния плотности ТН на нефтеемкость верхового, переходного и низинного торфа показало прямопропорциональную зависимость (табл. 9, 10). Ранее подобная закономерность была установлена в работах $[10,11]$ - возрастание нефтеемкости сорбентов с ростом плотности сорбтива (турбинное масло, бензин, мазут дизельное топливо).

Таблица 9. Зависимость нефтеемкости $\boldsymbol{G}_{\boldsymbol{N}}{ }^{\boldsymbol{d}}$ верхового торфа от плотности товарной нефти

\begin{tabular}{|c|c|c|c|c|c|c|}
\hline \multirow{2}{*}{$\begin{array}{c}\text { Шифр товар- } \\
\text { ной нефти }\end{array}$} & \multirow{2}{*}{ 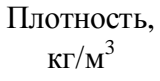 } & \multicolumn{5}{|c|}{ Нефтеемкость верхового торфа, $\boldsymbol{G}_{\boldsymbol{N}}{ }^{d}$, г ТН/1 г торфа } \\
\hline & & $763-8, \mathrm{R}=5 \%$ & $817-4, \mathrm{R}=5 \%$ & $933-2, R=20 \%$ & $768-4, \mathrm{R}=25 \%$ & $542-3, \mathrm{R}=35 \%$ \\
\hline $\mathrm{A}$ & 873,2 & 9,98 & 8,28 & 3,62 & 3,36 & 1,66 \\
\hline B & 844,3 & 9,17 & 8,07 & 3,06 & 2,87 & 1,61 \\
\hline $\mathrm{C}$ & 824,0 & 9,02 & 7,28 & 2,22 & 2,71 & 1,42 \\
\hline $\mathrm{D}$ & 796,2 & 8,50 & 6,02 & 1,64 & 2,68 & 1,37 \\
\hline
\end{tabular}

Таблица 10. Зависимость нефтеемкости $\boldsymbol{G}_{\boldsymbol{N}}{ }^{\boldsymbol{d}}$ переходного и низинного торфа от плотности товарной нефти

\begin{tabular}{|c|c|c|c|c|c|}
\hline \multirow{3}{*}{$\begin{array}{c}\text { Шифр товарной } \\
\text { нефти }\end{array}$} & \multirow{3}{*}{ 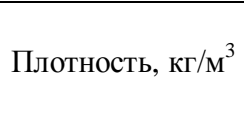 } & \multicolumn{4}{|c|}{ Нефтеемкость торфа, $\boldsymbol{G}_{N}{ }^{d}$, г ТН/1 г торфа } \\
\hline & & \multicolumn{2}{|c|}{ переходного } & \multicolumn{2}{|c|}{ низинного } \\
\hline & & $768-5, \mathrm{R}=20 \%$ & $397-2, \mathrm{R}=30 \%$ & $932-3, \mathrm{R}=30 \%$ & $972-1, \mathrm{R}=35 \%$ \\
\hline A & 873,2 & 2,88 & 3,46 & 4,25 & 4,26 \\
\hline $\mathrm{B}$ & 844,3 & 2,84 & 3,22 & 2,76 & 3,50 \\
\hline $\mathrm{C}$ & 824,0 & 2,85 & 3,02 & 2,59 & 3,43 \\
\hline $\mathrm{D}$ & 796,2 & 2,16 & 2,48 & 2,11 & 2,65 \\
\hline
\end{tabular}




\section{Выводы}

1. Установлено, что нефтеемкость $\boldsymbol{G}_{N}{ }^{d}$ изученных торфов для товарных нефтей A, B, C, D находится в пределах от 9,98-1,37 г/1 г торфа, для стабильного газового конденсата - 3,09-1,31 г/1 г торфа.

2. Наибольшая нефтеемкость $G_{N}{ }^{d}$ характерна для верховых торфов малой степени разложения, $\mathrm{R}=$ $5 \%$, сфагново-мочажинного и сфагнового видов.

3. Отмечена тенденция снижения нефтеемкости с ростом степени разложения для верховых торфов и увеличения нефтеемкости с ростом степени разложения для переходных и низинных торфов.

4. Установлено, что область распределения показателя нефтеемкости $G_{N}{ }^{d}$ для верховых, переходных, низинных торфов средней степени разложения $(\mathrm{R}=20-35 \%)$ по отношению к товарной нефти и стабильному газовому конденсату: наибольшая - для осокового торфа низинного типа ( $\mathrm{R}=35 \%)$, наименьшая для пушицево-сфагнового торфа верхового типа $(\mathrm{R}=35 \%)$.

5. Изучено влияние групповых составляющих торфа различного типа, вида и степени разложения на его нефтеемкость.

6. Показано, что величина $G_{N}{ }^{d}$ торфа зависит от плотности товарной нефти: чем выше плотность сорбируемой нефти, тем выше показатель нефтеемкости $G_{N}{ }^{d}$.

\section{Список литературь}

1. Каменщиков Ф.А., Богомольный Е.И. Удаление нефтепродуктов с водной поверхности и грунта. М.; Ижевск, 2006. $528 \mathrm{c}$.

2. Передерий М.А., Кураков Ю.И., Маликов И.Н., Молчанов С.В. Сорбция нефтепродуктов углеродными сорбентами // Химия твердого топлива. 2009. №5. С. 42-46.

3. Лиштван И.И., Базин Е.Т., Гамаюнов Н.И. Физика и химия торфа. М., 1989. 304 с.

4. Гамаюнов Н.И., Гамаюнов С.Н. Сорбция в гидрофильных материалах. Тверь, 1997. 160 с.

5. Новоселова Л.Ю., Сироткина Е.Е. Сорбенты на основе торфа для очистки загрязненных сред // Химия твердого топлива. 2008. №4. С. 64-77.

6. Испирян С.Р. Разработка методики комплексной оценки поглощения торфом нефтемаслопродуктов: дис. ... канд. техн. наук. Тверь, 2001. 151 с.

7. Лиштван И.И., Король Н.Т. Основные свойства торфа и методы их определения. Минск, 1975. 320 с.

8. Чухарева Н.В., Шишмина Л.В. Сравнение сорбционных свойств торфа верхового и низинного типа по отношению к товарной нефти и стабильному газовому конденсату // Химия растительного сырья. 2012. C. $193-200$.

9. Бурмистрова Т.И., Алексеева Т.П., Стахина Л.Д., Середина В.П. Исследование свойств торфа для решения экологических проблем // Химия растительного сырья. 2009. №3. С. 157-160.

10. Сергеева Е.С. Комплексное использование торфа на ТЭС: дис. ... канд. техн. наук. Казань, 2008. 151 с.

11. Темирханов Б.А. Исследование сорбционных свойств углеродсодержащих материалов при ликвидации нефтяных загрязнений: дис. ... канд. хим. наук. Краснодар, 2005. 126 с.

12. Чухарева Н.В., Шишмина Л.В., Новиков А.А. Исследование гуминовых кислот исходных и термообработанных торфов Томской области. Томск, 2010. 192 с. 
Chukhareva N.V., Shishmina L.V., Maslov S.G. DEFINING OIL SORPTION CAPACITY OF PEAT SAMPLES FROM TOMSK REGION

Tomsk Polytechnic Univesity, Lenin Prospect, 30, Tomsk, 634034 (Russia), e-mail: natasha@tpu.ru

Assessed the ability of different types of peat and the type and degree of decomposition sorb crude oil and a stable gas condensate. Shows the effect of the degree of decomposition, the group composition of peat on the oil intensity. It was found that the sorption properties of all the samples of peat depends on the density of adsorbed petroleum hydrocarbons.

Keywords: peat, peat decay degree, fractional composition, technical analysis, group composition, sorption properties, chemical structure, natural sorbents, oil, gas condensate, oil sorption capacity, distribution area.

\section{References}

1. Kamenshchikov F.A., Bogomol'nyi E.I. Udalenie nefteproduktov s vodnoi poverkhnosti i grunta. [Removal of oil from the water surface and ground]. Moscow; Izhevsk, 2006, 528 p. (in Russ.).

2. Perederii M.A., Kurakov Iu.I., Malikov I.N., Molchanov S.V. Khimiia tverdogo topliva, 2009, no. 5, pp. $42-46$. (in Russ.).

3. Lishtvan I.I., Bazin E.T., Gamaiunov N.I. Fizika i khimiia torfa. [Physics and chemistry of peat]. Moscow, 1989, 304 p. (in Russ.).

4. Gamaiunov N.I., Gamaiunov S.N. Sorbtsiia v gidrofil'nykh materialakh. [Sorption in hydrophilic materials]. Tver, 1997, 160 p. (in Russ.).

5. Novoselova L.Iu., Sirotkina E.E. Khimiia tverdogo topliva, 2008, no. 4, pp. 64-77. (in Russ.).

6. Ispirian S.R. Razrabotka metodiki kompleksnoi otsenki pogloshcheniia torfom neftemasloproduktov: dis. ... kand. tekhn. nauk. [Development of methodology for integrated assessment of absorption peat neftemasloproduktov: Candidate of Technical Sciences thesis.]. Tver, 2001, 151 p. (in Russ.).

7. Lishtvan I.I., Korol' N.T. Osnovnye svoistva torfa i metody ikh opredeleniia. [Basic properties of peat and methods for determining]. Minsk, 1975, 320 p. (in Russ.).

8. Chukhareva N.V., Shishmina L.V. Khimiia rastitel'nogo syr'ia, 2012, no. 4, pp. 193-200. (in Russ.).

9. Burmistrova T.I., Alekseeva T.P., Stakhina L.D., Seredina V.P. Khimiia rastitel'nogo syr'ia, 2009, no. 3, pp. 157-160. (in Russ.).

10. Sergeeva E.S. Kompleksnoe ispol'zovanie torfa na TES: dis. ... kand. tekhn. nauk. [Integrated use of peat to the power station: Candidate of Technical Sciences thesis.]. Kazan, 2008, 151 p. (in Russ.).

11. Temirkhanov B.A. Issledovanie sorbtsionnykh svoistv uglerodsoderzhashchikh materialov pri likvidatsii nef-tianykh zagriaznenii: dis. ... kand. khim. nauk. [Investigation of the sorption properties of carbonaceous materials in the elimination of oil pollution: Candidate of Chemical Sciences thesis]. Krasnodar, 2005, 126 p. (in Russ.).

12. Chukhareva N.V., Shishmina L.V., Novikov A.A. Issledovanie guminovykh kislot iskhodnykh i termoobrabotan-nykh torfov Tomskoi oblasti. [The study of humic acid and heat-treated raw peat of Tomsk region]. Tomsk, 2010, $192 \mathrm{p}$. (in Russ.).

\footnotetext{
* Corresponding author.
} 
